\title{
Obstetric outcome of phase IV of National AIDS Control Programme at a tertiary care centre
}

\author{
Vijay Y. Kalyankar*, Bhakti V. Kalyankar, Shriniwas N. Gadappa, Ummehani G. Rasool
}

Department of Obstetrics and Gynaecology, Government Medical College, Aurangabad, Maharashtra, India

Received: 03 August 2017

Accepted: 01 September 2017

\section{*Correspondence:}

Dr. Vijay Y. Kalyankar,

E-mail: vijukalyankar@ rediffmail.com

Copyright: (C) the author(s), publisher and licensee Medip Academy. This is an open-access article distributed under the terms of the Creative Commons Attribution Non-Commercial License, which permits unrestricted non-commercial use, distribution, and reproduction in any medium, provided the original work is properly cited.

\section{ABSTRACT}

Background: This study was conducted to observe maternal and fetal outcome of sero-positive women delivering at our centre by using the newly introduced National AIDS Control Programme (NACP) phase IV of HARRT (highly active antiretroviral therapy) recommended by National AIDS Control Organisation (GOI) started from $1^{\text {st }}$ January 2014.

Methods: Study included all seropositive pregnant women diagnosed during pregnancy and in emergency at labour room of Government Medical College, Aurangabad, Maharashtra, India in 2 years period. The women and their newborns were managed as per recommendations of phase IV of National AIDS Control Programme of Government of India.

Results: There was reduction in associated maternal infections, high CD4 counts, increase in vaginal deliveries, promotion of exclusive breast feeding and limitation of vertical transmission of HIV. The adverse impact of HIV on mother and newborn still continues.

Conclusions: Phase IV of NACP appears to be promising in the initial phases of its implementation.

Keywords: NACO, Phase IV of NACP, Sero positive pregnant women

\section{INTRODUCTION}

The HIV global impact is described as "epidemic of our century". India has 2-3 million people living with HIV/AIDS of which $40.5 \%$ are females. ${ }^{1,2}$ In 2015 , adult HIV prevalence was estimated at $0.30 \%$ among males and at $0.22 \%$ among females. NACP Phase III (20072013) programme was started by NACO and it recommended use of single dose of Nevirapine (200mg) at the onset of labour and syrup Nevirapine to newborns. This regimen was less effective than other ARV prophylaxis and it also adds to the risk of acquiring drug resistance to Nevirapine and cross resistance to Efavirenz, so policy was reviewed by NACO. The drawbacks of Phase III were eliminated and NACP Phase IV was started from $1^{\text {st }}$ January 2014. In Phase IV, the newer guidelines suggest initiating lifelong ART (Triple drug regime) for all pregnant women living with HIV, regardless of CD4 count or WHO clinical stage and syrup Nevirapine to babies for 6 weeks. It also recommends caesarean section only for obstetric indications and promotes preferably exclusive breast feeding in developing countries unlike in Phase III. In 2015, WHO released new guidelines which recommend providing lifelong ART to all pregnant and breastfeeding women living with HIV regardless of CD4 count or WHO clinical staging (WHO PMTCT Guidelines AVERT). In short both NACP phase 4 and WHO recommend the same.

HIV/AIDS infection is an important cause of maternal and perinatal morbidity/mortality. Anaemia, preterm labour, intrauterine growth retardation (IUGR), fetal deaths, stillbirths, low birth weight, low Apgar scores are some of the known complications associated with HIV in pregnancy. As Maharashtra is amongst high prevalence 
states for people living with HIV and our institute is one of the busiest tertiary care centre in Maharashtra catering both ART centre and maternity services for HIV case, we conducted this study to observe maternal and fetal outcome delivering at our centre by using the phase IV NACP of HARRT recommended by NACO (Government of India) started with effect from $1^{\text {st }}$ January $2014 .^{3}$

Objective of this study was to study maternal and fetal outcome in HIV infected pregnant women at tertiary care centre using the newly introduced Phase IV NACP by NACO.

\section{METHODS}

The present study was an observational prospective study.

\section{Inclusion criterion}

- All seropositive pregnant women diagnosed at antenatal clinic or ART clinic or both, delivered at our institute

- All seropositive pregnant women diagnosed in emergency and delivered in our institute and outside.

\section{Exclusion criterion}

All Seropositive pregnant women whose pregnancies ended in spontaneous and missed abortions.

This study was conducted from November 2014 to November 2016 at Government Medical College, Aurangabad, Maharashtra, India as per guidelines issued under phase IV of NACP by NACO. ${ }^{3}$

The study was started after approval from the local Institutional ethical committee and NACO. Written, informed and valid consent was obtained from participants willing to participate. Total 50 seropositive pregnant women were detected. All cases were referred to antiretroviral therapy centre of our Institute and started on HARRT.

Cases positive for STD's were sent to speciality clinics. If cases with TB, HIV-II, Hepatitis B and C were found, they were referred to speciality clinics. CD 4 counts of all participants were noted. Details of ongoing medication including ART were noted. Special investigations like serum LDH, PT, INR, serum electrolytes were done for special cases as per requirement. The ongoing triple therapy (HARRT) was continued for the women who were in latent phase as per their schedule. Those who were in labour were given intrapartum TLE (Tenofovir, Lamivudine and Efavirenz). Antibiotic inj. Cefotaxime 1 g, 12-hourly IV and inj. Metronidazole $500 \mathrm{mg} 8$ hourly were started to all women in labour and was continued 72 hours after delivery. All universal precautions were taken by all health care takers at the time of delivery. Induction of labour and caesarean section were done only for obstetric indications. Women were counseled about feeding the baby. Exclusive breast feeding was preferably advised though the choice of exclusive breast feeding or top feeding was given to mothers. Feeding was started as early as possible after delivery. Baby examination at delivery included baby weight, APGAR score at $5 \mathrm{~min}$., NICU admission if any. Syrup Nevirapine $2 \mathrm{mg} / \mathrm{kg}$ was given to all live babies as early as possible and mothers were counseled to continue it daily up to 6weeks. Contraception was advised to all participants depending on their need. Lifelong use of condoms was advised to all women even if they were using other contraceptive method. Women were advised to continue ART lifelong.

Participants in phase IV also included:

- Women who received NACP Phase III in previous pregnancy were now taken under Phase IV in this pregnancy.

- Women who were already on ART and then become pregnant.

- Women who delivered outside and were referred to our institute and found to be positive.

- Women who were detected sero-positive in emergency were sent to ART centre for confirmation test and if found to be positive were put on HARRT.

- Women who were already on ART and defaulted the treatment and become pregnant were again counseled and put on $\mathrm{ART}^{3}$

Patients were monitored for side effects of ART. Spouse testing and couple counseling about safe sexual practices was done. Nutritional advice was given to all. Monthly visit in ART was ensured. Schedule of ANC visit was similar to that of sero-negative pregnant women. Women with co-infections were asked to visit more frequently. All diagnosed women received HAART both ante partum and intra partum. ${ }^{3}$

\section{Care during labour}

After cleaning vagina with povidone iodine solution, per vaginal examination was done every 4-hourly. Artificial rupture of membranes was avoided and done only if indicated. Perineal support given and episiotomy was given only if required. No investigations were done on umbilical cord blood. OPV (live attenuated) was not given. Rest immunization was done as per National Immunization Programme. Babies were continued on syrup Nevirapine $2 \mathrm{mg} / \mathrm{kg}$ weight and early infant diagnosis was done at 6 weeks of age. Both mother and baby were followed at 6 weeks for compliance and treat if any associated infections. ${ }^{3}$ Confidentiality of all data and results was maintained.

\section{RESULTS}

10421 women were tested for HIV in 2 years, 48 were found positive in antenatal clinics and 2 in emergency admissions at labour room. Incidence was $0.47 \%$. 
Table 1: Socio-demographic profile of cases.

\begin{tabular}{|c|c|c|}
\hline Profile & Class & Number $=\mathbf{5 0}$ \\
\hline \multirow{4}{*}{ Age in years } & $19-24$ & 26 \\
\hline & $25-29$ & 11 \\
\hline & $30-34$ & 10 \\
\hline & $>34$ & 03 \\
\hline \multirow{3}{*}{ Education level } & Primary & 28 \\
\hline & Secondary & 20 \\
\hline & Tertiary & 02 \\
\hline \multirow{3}{*}{$\begin{array}{l}\text { Socio-economic } \\
\text { class }\end{array}$} & Lower & 36 \\
\hline & Middle & 14 \\
\hline & Higher & 00 \\
\hline \multirow{3}{*}{ Religion } & Hindu & 45 \\
\hline & Muslim & 05 \\
\hline & Others & 00 \\
\hline \multirow{2}{*}{ Residence } & Urban & 31 \\
\hline & Rural & 19 \\
\hline \multirow{3}{*}{$\begin{array}{l}\text { Sero-status of } \\
\text { spouse }\end{array}$} & Reactive & 45 \\
\hline & Non-reactive & 04 \\
\hline & Not tested & 01 \\
\hline \multirow{3}{*}{ Gravidity } & Primigravida & 18 \\
\hline & Second gravida & 16 \\
\hline & Multigravida & 16 \\
\hline
\end{tabular}

Table 2: Clinical presentation of cases.

\begin{tabular}{|c|c|c|}
\hline Signs and Symptoms & No $=50$ & Percentage (\%) \\
\hline Genital candidiasis & 8 & 16 \\
\hline $\begin{array}{l}\text { Oral herpes (herpes } \\
\text { labialis) }\end{array}$ & 6 & 12 \\
\hline Genital ulcers & 0 & 00 \\
\hline Oral ulcers & 9 & 18 \\
\hline Genital warts & 0 & 00 \\
\hline Tuberculosis & 0 & 00 \\
\hline Hepatitis B & 0 & 00 \\
\hline Syphilis & 0 & 00 \\
\hline UTI/Pneumonia & 0 & 00 \\
\hline
\end{tabular}

Table 3: Gestational age at initiation of ART.

\begin{tabular}{|lll|}
\hline $\begin{array}{l}\text { Gestational age in } \\
\text { weeks }\end{array}$ & $\mathbf{N}=50$ & Percentage (\%) \\
\hline Preconception & 21 & 43.75 \\
\hline$<14$ & 05 & 10.41 \\
\hline $14-28$ & 08 & 16.66 \\
\hline$>28$ & 14 & 29.16 \\
\hline Intrapartum & 02 & 04.00 \\
\hline Total & 48 & 100 \\
\hline
\end{tabular}

In the study $43.75 \%$ of the participants were on ART preconceptionally.

$56 \%$ had low education and $72 \%$ were from low socioeconomic class. Poverty and low education favoured HIV infection. $100 \%$ were housewives. $71 \%$ were between 19 29 years of age. $89.79 \%$ had husband infected with HIV.
$100 \%$ women underwent pre-and post-test counseling. $100 \%$ women were compliant to ART and none had any side effects.

Nobody required third line ART. 4\% women, diagnosed in emergency received ART intra-partum only and all rest received both ante-partum and intra-partum.

Table 4: Gestational age at delivery.

\begin{tabular}{|l|l|l|}
\hline Gestational age & No=50 & Percentage (\%) \\
\hline $28-33.6$ & 4 & 8 \\
\hline $34-36.6$ & 4 & 8 \\
\hline $37-40$ & 33 & 66 \\
\hline$>40$ & 9 & 18 \\
\hline Total & 50 & 100 \\
\hline
\end{tabular}

$66 \%$ of patients delivered at term \& mean gestational age was 39.1 weeks

$16 \%$ of the patient underwent preterm births, $4 \%$ had IUGR, $8 \%$ had IUFD's and $8 \%$ needed blood transfusion for anemia. IUFD babies weighed between 1.7 to $2.3 \mathrm{~kg}$.

Table 5: Antenatal obstetric complications.

\begin{tabular}{|lll|}
\hline Complications & No=50 & Percentage $(\%)$ \\
\hline Preterm birth & 8 & 16 \\
\hline PROM & 5 & 10 \\
\hline PIH & 3 & 6 \\
\hline IUGR & 2 & 4 \\
\hline Oligohydramnios & 3 & 6 \\
\hline IUFD & 4 & 8 \\
\hline Chorioamnionitis & 0 & 0 \\
\hline Anemia & 4 & 8 \\
\hline
\end{tabular}

Table 6: Mode of delivery.

\begin{tabular}{|llll|}
\hline $\begin{array}{l}\text { Mode of } \\
\text { delivery }\end{array}$ & N=50 & $\begin{array}{l}\text { Percentage } \\
(\%)\end{array}$ \\
\hline \multirow{4}{*}{$\begin{array}{l}\text { Vaginal } \\
\text { delivery }\end{array}$} & Spontaneous & 32 & 64 \\
\cline { 2 - 4 } & Forceps/vacuum & 0 & 00 \\
\cline { 2 - 4 } & Assisted vaginal & 0 & 00 \\
\cline { 2 - 4 } & VBAC & 2 & 04 \\
\cline { 2 - 4 } $\begin{array}{l}\text { Caesarean } \\
\text { delivery }\end{array}$ & Elective & 9 & 18 \\
\hline & Emergency & 2 & 04 \\
\hline
\end{tabular}

LSCS were done only for Obstetric indications. Out of 9 Caesarean sections, 2 were done for foetal distress, 5 were done for previous LSCS with associated complications, and 1 each for CPD and severe Oligohydramnios.

$32 \%$ babies were LBW, 16\% had low apgar scores and $16 \%$ needed NICU admissions. After giving choice, $60 \%$ had exclusive breast feeding and $40 \%$ had top feeding. None had mixed feeding. $100 \%$ live babies received Nevirapine syrup upto 6 weeks. Sero status of all babies at 6 weeks by DNA-PCR was negative. 


\section{DISCUSSION}

$62 \%$ women belonged to Urban areas. This finding is similar to studies done by Turner BJ $(82.41 \%)$ and Joshi et al $(54.77 \%) .{ }^{4,5}$ More cases probably are detected from urban areas than rural
The studies done by Goswami et al had (83.23\%), Joshi et al had (65.3\%), Gupta et al had (70\%), seropositive husband..$^{5-7}$ Present study showed still more $(89.79 \%)$. More and more partners are complying counseling and test to know personal infectivity.

Table 7: Timing of diagnosis of HIV.

\begin{tabular}{|llllll|}
\hline Study name & Preconception in percentage & First trimester & Second trimester & Third trimester & During labour \\
\hline Joshi et $\mathrm{al}^{5}$ & 0 & 8.6 & 30.9 & 46.9 & 13.6 \\
\hline Gupta et $\mathrm{al}^{7}$ & 0 & 22.03 & 33.09 & 44.86 & 0 \\
\hline Present study & 43.75 & 10.41 & 16.66 & 29.16 & 4 \\
\hline
\end{tabular}

Table 8: CD4 Counts.

\begin{tabular}{|c|c|c|c|}
\hline Study name & $<200(\%)$ & $200-499(\%)$ & $>500(\%)$ \\
\hline Townsend Schulte et al ${ }^{10}$ & 12.1 & 48.2 & 39.7 \\
\hline Claire et al $^{9}$ & 12.1 & 52.8 & 35.1 \\
\hline Mayaux et al ${ }^{11}$ & 7.9 & 37.69 & 54.36 \\
\hline Thea et $\mathrm{al}^{12}$ & 9.8 & 41.17 & 49.01 \\
\hline Present study & 2.0 & 33.33 & 64.58 \\
\hline
\end{tabular}

Table 9: Mode of delivery.

\begin{tabular}{|c|c|c|c|}
\hline Study name & Vaginal delivery & Elective LSCS & Emergency LSCS \\
\hline Kind et al $^{16}$ & 54.61 & 28.39 & 8.73 \\
\hline Claire et $\mathrm{al}^{9}$ & 22.2 & 57.1 & 20.7 \\
\hline Azria et al ${ }^{17}$ & 45.0 & 38.0 & 17.0 \\
\hline Present study & 82.0 & Not done & 18.0 \\
\hline
\end{tabular}

Table 10: Newborn characteristics.

\begin{tabular}{|c|c|c|c|c|}
\hline Studies & Birth weight $<2.5 \mathrm{~kg}$ & 5 min Apgar score $<7$ & NICU admissions & Stillbirths \\
\hline Musana et al ${ }^{18}$ & $58 \%$ & $28 \%$ & $27 \%$ & $4 \%$ \\
\hline Ezechi et al ${ }^{19}$ & $9.4 \%$ & $2.7 \%$ & $3.9 \%$ & $5.5 \%$ \\
\hline Jenny Coley et $\mathrm{al}^{20}$ & $15.2 \%$ & $9.4 \%$ & $4.6 \%$ & $6.5 \%$ \\
\hline Lindsay et $\mathrm{al}^{21}$ & $27.7 \%$ & $3.4 \%$ & $17.8 \%$ & $0.0 \%$ \\
\hline Present study & $32 \%$ & $16 \%$ & $16 \%$ & $8 \%$ \\
\hline
\end{tabular}

Table 7 shows that $43.75 \%$ were diagnosed preconceptionally, i.e. in last pregnancy. Since they received HAART, the CD4 counts could be higher than in other Studies.

The compliance to ART increased with time as in, Tereza $\mathrm{M}$ et al in 2000 (75.8\%), Townsend et al in $2006(92.5 \%)$ and $100 \%$ in the present study. ${ }^{8,9}$ The increased public awareness of the NACO programme in India has probably increased it.

Table 8 shows $64.58 \%$ women had high CD4 counts in the present study. It also indicates why the major coinfections like TB, hepatitis B are not seen in women.

Leory et al (22.7\%), Kennedy et al (21\%), Kim et al $(14.3 \%)$ had Preterm deliveries. ${ }^{13-15}$ It was $16 \%$ in the present study. Thus, the adverse impact of HIV on both mother and baby still continues.

NACP phase IV does not recommend elective LSCS to prevent MTCT. $^{3}$ We did LSCS only for obstetric indications as per recommendations. The other studies had a high rate as in the previous phases; NACO recommended LSCS to reduce the vertical transmission rate.

Infants of mothers with HIV are more likely to have LBWs, low Apgar scores and stillbirths. Table 10 shows an association between maternal HIV infection and LBW babies and low Apgar score in various studies. Like in other Studies, it continues to be still high, even with phase IV of NACP. In the present study, feeding practice as per phase IV, was totally mother's choice. $60 \%$ chose exclusive breast feeding and $40 \%$ chose formula feeds 
with none as mixed feeding. In study of Goswami et al, $29.47 \%$ had breast feeding and $70.52 \%$ gave formula feeds. ${ }^{6}$ Joshi et al study reveals $95 \%$ exclusive breast feeding and $3.4 \%$ formula feeds and $1.6 \%$ mixed feeding. ${ }^{5}$ Exclusive breast feeding prevents other neonatal infections.

In studies conducted at Malawi, Abidjan and Kenya, the maternal to child transmission was $7.7 \%, 6.5 \%$ and $5 \%$ respectively. This was $0 \%$ in the present study at 6 weeks of follow up by DNA-PCR studies.

The newborns in the present study were followed up till 6 weeks only. The DNA-PCR report needs to be followed up again at 18 months of age. This is the limitation in the present study. Further research is needed to follow up at 18 months.

\section{CONCLUSION}

The NACP phase IV differs in comparison to previous phases in that, it recommends lifelong HAART to all sero-positive women, integrated detection and treatment of associated infections, promotes vaginal deliveries and LSCS only for obstetric indications, advocates exclusive breastfeeding though gives choice with formula feeding (only one of the two), and syrup Nevirapine for upto 6 weeks to all newborns. Accordingly, phase IV seems to be promising in reducing associated infections, increasing vaginal deliveries and limiting vertical transmission. However, the adverse impact of HIV on pregnancy and neonatal outcome in terms of maternal anemia, preterm births, low birth weight babies, low Apgar scores, NICU admissions and stillbirths still continue.

Funding: No funding sources Conflict of interest: None declared

Ethical approval: The study was approved by the Institutional Ethics Committee

\section{REFERENCES}

1. National Control Organization (NACO). HIV Sentinel Surveillance and HIV Estimation in India 2007. Available at http://www.nacoonline.org/upload/Publication/M\&E $\% 20$.

2. UNAIDS. Asia:AIDS epidemic summary regional summary. 2008. Available at http://data.unaids.org/pub/Report/2008/jc1527_epibri efs_asia_en_pdf.

3. National Aids Control Organization. Revised national PPTCT guidelines by NACO. 2014.

4. Turner BJ, Newschaffer CJ, Cocroft J, Fanning TR, Marcus S, Hauck WW. Improved birth outcomes among HIV-infected women with enhanced Medicaid prenatal care. Am J Public Health. 2000;90(1):85.

5. Joshi U, Patel S, Shah K, Oza U, Modi U. Studying PPTCT services, interventions, coverage and utilization in India. J Glob Infect Dis. 2011;3(4):3717.

6. Goswami S, Chakravorty PS. Prevention of Parent to Child Transmission of HIV (PPTCT). An effort of 4 years in a Tertiary Centre. J Obstet Gynaecol India. 2011;61(4):394-8.

7. Gupta RS, Hegde A. Descriptive study of the utility of individual tracking tool in program monitoring for prevention of mother to child transmission of HIV, Maharashtra, India. Curr Opin HIV AIDS. 2016;11(1):30.

8. Monreal MT, Cunha RV, Trinca LA. Compliance to antiretroviral medication as reported by AIDS patients assisted at the University Hospital of the Federal University of Mato Grosso do Sul. Br J Infect Dis. 2002;6(1):08-14.

9. Townsend C. Antiretroviral therapy and pregnancy outcome in HIV infected women in the United Kingdom and Ireland. University College, London. 2009.

10. Townsend C, Schulte J, Thorne C, Dominguez KI, Tookey PA, Cortina-Borja M, et al. Antiretroviral therapy and preterm delivery: a pooled analysis of data from the United States and Europe. BJOG. 2010;117(11):1399-410.

11. Mayaux MJ, Dussaix E, Ispoet J, Rekacewicz C, Mandelbrot L, Vigneron CN, et al. Maternal viral load during pregnancy and mother to child transmission of human immunodeficiency virus type 1. The French Perinatal Cohort Studies. J Infect Dis 1997; 175:172-5.

12. Thea DM, Steketee RW, Pliner V, Bornschlegel K, Brown T, Orloff $S$, et al. The effect of maternal viral load on the risk of perinatal transmission of HIV-1. New York City Perinatal HIV Transmission Collaborative Study Group. 1997;11(4):437-44.

13. Leroy V, Ladner J, Nyiraziraje M, De Clercq A, Bazubagira A, Van de Perre P, et al. Pregnancy and HIV Study Group. Effect of HIV-1 infection on pregnancy outcome in women in Kigali, Rwanda, 1992-1994. AIDS. 1998;12(6):643-50.

14. Kennedy D. The effect of maternal HIV status on perinatal outcome at Mowbray Maternity Hospital and referring midwife obstetric units, Capetown. SAJOG. 2012;18(1):7-10.

15. Kim HY, Kasonde P, Mwiya M, Thea DM, Kankasa C, Sinkala M, et al. Pregnancy loss and role of infant HIV status on perinatal mortality among HIV infected women. BMC Pediatr. 2012;12:138.

16. Kind C, Rudin C, Siegrist CA, Wyler CA, Biedermann K, Lauper U, et al. Prevention of vertical HIV transmission: additive protective effect of elective cesarean section and Zidovudine prophylaxis. Swiss Neonatal HIV Study Group. AIDS. 1998;12(2):205-10.

17. Azria E. Pregnancy outcomes in women with HIV type-1 receiving a lopinavir/ritonavir containing regimen. Int Med Press. 2009:1359-6535. 
18. Musana JW. Pregnancy outcomes in mothers with advanced human immunodeficiency virus disease. East Afr Med J. 2009;86(10):480-5.

19. Ezechi OC. Pregnancy, obstetric and neonatal outcomes in HIV positive Nigerian women. Afr J Reproductive Health. 2013;17(3):160-8.

20. Coley JL. The association between maternal HIV-1 infection and pregnancy outcomes in Dar es Salaam, Tanzania. BJOG. 2001;108:1125-33.

21. Alger, Lindsay S, Farley, John J, Robinson, Barbara A, et al. Interactions of Human Immunodeficiency virus infections and pregnancy. Obstet Gynecol. 1993;82(5):787-96.

Cite this article as: Kalyankar VY, Kalyankar BV, Gadappa SN, Rasool UG. Obstetric outcome of Phase IV of National AIDS Control Programme at a tertiary care centre. Int J Reprod Contracept Obstet Gynecol 2017;6:4555-60. 